Penerbit:

Program Studi Magister Ilmu Kesehatan Masyarakat, Program Pascasarjana, Universitas Sam Ratulangi

Indonesian Journal of Public Health and Community Medicine is indexed by Google Scholar and licensed under a Creative Commons Attribution 4.0 International License.

\title{
Citra Tubuh, Pengetahuan, Sikap dan Tingkat Aktivitas Fisik Mahasiswa pada Masa Pandemi Corona Virus Disease 2019
}

\author{
${ }^{1}$ Perdinan Manangkabo, ${ }^{2}$ Bernabas Harold Ralph Kairupan, ${ }^{2}$ Aaltje Ellen \\ Manampiring
}

\author{
${ }^{1}$ Program Studi Ilmu Kesehatan Masyarakat Program Pascasarjana Universitas Sam Ratulangi \\ ${ }^{2}$ Fakultas Kedokteran Universitas Sam Ratulangi \\ E-mail: pmanangkabo@gmail.com
}

\begin{abstract}
Abstrak
Latar Belakang: World Health Organization (WHO) menyatakan bahwa Coronavirus disease (Covid-19) sebagai pandemi global pada tanggal 11 Maret 2020. Negara-negara di dunia terdampak, termasuk Indonesia. Semua aktivitas diluar rumah dibatasi, termasuk aktivitas fisik. Citra tubuh, pengetahuan, dan sikap merupak faktor mempengaruhi aktivitas fisik. Tujuan penelitian ini yaitu untuk melihat korelasi antara citra tubuh, pengetahuan, dan sikap dengan tingkat aktivitas fisik pada mahasiswa Fakultas Kesehatan Masyarakat Universitas Sam Ratulangi (FKM UNSRAT) selama pandemi Covid-19. Metode Penelitian: Penelitian ini menggunakan pendekatan kuantitatif, dengan metode survei dan tekhnik analisis asosiatif (korelasional). Tekhnik pengambilan sampel adalah purposive sampling. Penelitian ini dilaksanakan di FKM Unsrat mahasiswa minat Kesehatan dan Keselamatan Kerja (K3) pada Januari 2021. Sampel dalam penelitian ini yaitu 60 mahasiswa. Variabel penelitian ini yaitu aktivitas fisik sebagai variabel terikat, citra tubuh, pengetahuan, dan sikap sebagai variabel bebas. Kuisioner sebagai alat ukur. Data hasil penelitian dianalisis secara univariat dan bivariate dengan uji chi-square. Hasil Penelitian: Hasil penelitian ditemukan citra tubuh dengan aktivitas cukup fisik pada kategori puas yaitu 92\%, pengetahuan kategori baik dengan aktivitas fisik cukup 85\%, sikap kategori baik dengan aktivitas fisik cukup 80\%. Hasil analisis bivariat menunjukkan terdapat hubungan antara citra tubuh, pengetahuan, dan sikap dengan tingkat aktivitas fisik pada mahasiswa FKM UNSRAT selama pandemi Covid-19. Kesimpulan: Kesimpulan penelitian ini yaitu faktor-faktor yang berhubungan dengan aktvitas fisik mahasiswa yaitu citra tubuh, pengetahuan dan sikap.
\end{abstract}

Kata Kunci: citra tubuh; pengetahuan; sikap; aktivitas fisik

\section{Abstract}

Background: The World Health Organization (WHO) declared the corona virus outbreak a global pandemic on March 11, 2020. Countries in the world affected, including Indonesia. All activities outside the home are limited, including physical activity. Citra tubuh, knowledge, and attitude are factors affecting physical activity. The purpose of this study was to see the correlation between citra tubuh, knowledge, and attitudes with the level of physical activity among students of the Faculty of Public Health, Sam Ratulangi University (FKM UNSRAT) during the Covid-19 pandemic. Methode: This research uses a quantitative approach, with survey methods and 
associative analysis techniques (correlational). The sampling technique was purposive sampling. This research was conducted at FKM Unsrat students with an interest in Occupational Health and Safety (K3) in January 2021. The sample in this study was 60 students from the total population. The variables of this research are physical activity as the dependent variable, citra tubuh, knowledge, and attitude as independent variables. Questionnaire as a measuring tool. The research data were analyzed by univariate and bivariate with the chi-square test. Data presentation is made in table and narrative form. Result: The results showed that citra tubuh with sufficient physical activity was in the satisfied category, namely 92\%, good category knowledge with sufficient physical activity was $85 \%$, good category attitude with adequate physical activity was $80 \%$. Bivariat analysis was showed that there are correlation between citra tubuh, knowledge, and attitudes with the level of physical activity among students of the FKM UNSRAT during the Covid-19 pandemic. Conclusion: The conclusion of this study is that the citra tubuh, knowledge, and attitudes were the factors correlated with the level of physical activity among students of the FKM UNSRAT during the Covid-19 pandemic.

Key words: body image; knowledge; attitude; physical activity

\section{PENDAHULUAN}

World Health Organization (WHO) atau Badan Kesehatan Dunia menetapkan wabah Coronavirus Disease-2019 (Covid-19), yang di sebabkan oleh virus SARS-CoV2, sebagai pandemi global pada tanggal 11 Maret 2020. Negara-negara terdampak termasuk Indonesia, menerapkan berbagai upaya dalam menekan penyebaran Covid-19. Social distancing, pembatasan semua kegiatan di luar rumah, beraktivitas dan bekerja dari rumah merupakan kebijakan yang diterapkan oleh hampir semua pimpinan negara. Didapatkan efek negatif dari kurungan rumah pada aktivitas fisik dan perilaku diet dengan peningkatan waktu duduk yang signifikan dan diet yang tidak sehat, menunjukan gaya hidup yang lebih santai. Aktivitas fisik memainkan peran penting dalam menjaga status gizi terutama pada komponen pengukuran Indeks Massa Tubuh (IMT) (Ammar 2020).

Aktivitas fisik adalah semua gerakan tubuh yang dihasilkan oleh otot rangka yang memerlukan pengeluaran energi. Hal itu bisa dilakukan dengan: berjalan, bersepeda, berenang, olahraga, dan bentuk kegiatan lainnya seperti menari, yoga atau bahkan mengerjakan pekerjaan rumah tangga. Semua aktivitas fisik akan memberikan manfaat untuk kesehatan jika dilakukan secara teratur dan dengan durasi serta intensitas yang cukup (WHO, 2018). Aktivitas fisik di Indonesia menurut data Riset Kesehatan Dasar (Riskesdas) 2018 masih sangat kurang yaitu $<50 \%$ (33,5\%). Jumlah ini mengalami peningkatan dari data Riskesdas 2013 sebesar 26,1 \%. Provinsi Sulawesi Utara juga mengalami peningkatan prevalensi masyarakat yang kurang beraktivitas fisik yaitu dari 25,2\% (2013) menjadi 33,5 \% (2018) (Kemenkes RI, 2018).

Kementrian Kesehatan mencatat kurangnya aktivitas fisik menyebabkan peningkatkan penyakit tidak menular, hipertensi salah satunya. Menurut penelitian Putra et al (2017), ditemukan bahwa lebih dari setengah responden yang mereka teliti memiliki pemahaman risiko obesitas yang baik namun tingkat aktivitas fisik mereka bertaraf sedang. Hasil penelitian dari Welong et al (2020) menunjukkan bahwa aktivitas fisik berkaitan dengan peningakatan prestasi akademik.

Saat ini, pandemi Covid-19 telah mendorong masyarakat untuk melakukan segala bentuk aktivitas di rumah, baik bekerja, belajar, maupun ibadah. Bilamana hal ini terus berlanjut, akan berdampak terhadap meningkatnya risiko timbulnya penyakit tidak menular. Hal ini, secara langsung maupun tidak langsung, berdampak terhadap berkurangnya aktivitas fisik masyarakat umumnya dan dikalangan mahasiswa khususnya. Mahasiswa sebagai bagian dari penerus bangsa harus mempersiapkan diri untuk 
membangun bangsa ini dengan kemampunya. Oleh karena itu, kondisi tubuh yang sehat dan bugar sangat di perlukan. Tingkat aktivitas fisik dapat dipengaruhi oleh yang tidak dapat dimodifikasi meliputi usia, jenis kelamin, ras, etnis, dan faktor yang dapat dimodifikasi meliputi karakteristik individu, dukungan sosial, lingkungan tempat tinggal, status ekonomi, pekerjaan, keterbatasan fisik, level pendidikan/pengetahuan dan kesempatan mengakses pelayanan kesehatan. Berdasarkan hasil penelitian yang dilakukan di Universitas Brawijaya bahwa tingkat aktivitas fisik yang rendah didapatkan 60\% dari mahasiswa tingkat kesatu, kedua, dan ketiga (Rizkawati et al, 2018).

Tentunya dimasa pandemi covid-19 seperti ini, semua jenis bentuk aktivitas fisik hanya bisa dilakukan dirumah saja. Ada banyak faktor yang mempengaruhi aktivitas fisik dari mahasiswa FKM. Citra tubuh, pengetahuan, dan sikap terhadap aktivitas fisik dari mahasiswa FKM UNSRAT minat Keselamatan dan Kesehatan Kerja tentunya berbedabeda. Pandemi covid-19 menyebabkan penurunan aktivitas fisik seseoran dan menyebabkan faktor resiko berbagai penyakit seperti obesitas, diabetes, hipertensi, dan jantung coroner (Nurhadi, 2020). Alasan mengambil sampel mahasiswa FKM UNSRAT minat K3 karena penelitian ini belum pernah di lakukan di FKM UNSRAT biang minat $\mathrm{K} 3$, mudah dijangkau dalam pengambilan data, mahasiswa sebagai role model melakukan pola hidup sehat dalam menunjang salah satu program pemerintah (GERMAS). Tujuan penelitian ini yaitu untuk melihat korelasi antara citra tubuh, pengetahuan, sikap dengan tingkat aktivitas fisik pada mahasiswa FKM UNSRAT selama pandemi covid-19

\section{METODE PENELITIAN}

Jenis penelitian ini yaitu asosiatif/ korelasional. Rancangan penelitian dengan cross sectional study. Penelitian ini dilakukan di FKM UNSRAT minat Kesehatan dan Keselamatan Kerja (K3) pada bulan Januari 2021. Subyek dalam penelitian ini yaitu mahasiswa FKM UNSRAT minat Kesehatan dan Keselamatan Kerja (K3). Populasi dalam penelitian berjumlah 60 mahasiswa, sampel adalah semua total populasi. Variabel dalam penelitian ini yaitu aktivitas fisik sebagai variabel terikat, citra tubuh, pengetahuan, sikap sebagai variabel bebas. Pertanyaan yang ditanyakan yaitu tentang aktivitas fisik, citra tubuh, pengetahuan, dan sikap. Data hasil penelitian dianalisis secara univariat dan bivariat. Analisis univariat bertujuan untuk mendeskripsikan karateristik variabel penelitian, sedangkan analisis bivariat menguji dua variabel independen (citra tubuh, pengetahuan, dan sikap) dengan variabel dependen (aktivitas fisik). Alat ukur yang digunakan yaitu kuisioner yang sudah divalidasi. Data diambil dengan menyebarkan kuisioner lewat aplikasi google form. Analisis data dilakukan secara univariat dan bivariat.

\section{HASIL DAN PEMBAHASAN}

Distribusi responden berdasarkan citra tubuh, pengetahuan, sikap, dan aktivitas fisik pada variabel penelitian dapat dilihat pada Tabel 1. 
Tabel 1. Hasil analisis univariat

\begin{tabular}{cccc}
\hline Variabel & Kategori & n & \% \\
\hline \multirow{3}{*}{ Body image } & Puas & 40 & 67 \\
& Tidak puas & 20 & 33 \\
& Total & 60 & 100 \\
\hline \multirow{3}{*}{ Pengetahuan } & Baik & 27 & 45 \\
& Cukup & 33 & 55 \\
& Total & 60 & 100 \\
\hline \multirow{3}{*}{ Sikap } & Baik & 40 & 67 \\
& Cukup & 20 & 33 \\
& Total & 60 & 100 \\
\hline \multirow{3}{*}{ Aktivitas fisik } & Cukup & 35 & 58 \\
& Kurang & 25 & 42 \\
& Total & 60 & 100 \\
\hline
\end{tabular}

Tabel 1 menunjukkan bahwa sebagian besar responden masuk pada kategori citra tubuh puas (67\%), pengetahuan yang cukup (55\%), sikap yang baik $(67 \%)$ dan aktivitas fisik yang cukup (58\%). Selanjutnya dilakukan analisis bivariat dimana hasilnya dapat dilihat pada Tabel 2.

Tabel 2. Hasil analisis bivariat

\begin{tabular}{|c|c|c|c|c|c|c|c|c|}
\hline \multirow{3}{*}{ Var. bebas } & \multirow{3}{*}{ Var. terikat } & \multicolumn{6}{|c|}{ Aktivitas Fisik } & \multirow{3}{*}{ Nilai $p$} \\
\hline & & \multicolumn{2}{|c|}{ Cukup } & \multicolumn{2}{|c|}{ Kurang } & \multicolumn{2}{|c|}{ Total } & \\
\hline & & $\mathrm{n}$ & $\%$ & $\mathrm{n}$ & $\%$ & $\mathrm{n}$ & $\%$ & \\
\hline \multirow[t]{3}{*}{ Body Image } & Puas & 35 & 92 & 3 & 8 & 38 & 100 & \\
\hline & Tidak Puas & 4 & 13 & 22 & 100 & 22 & 100 & 0.000 \\
\hline & Total & 35 & 58 & 25 & 42 & 60 & 100 & \\
\hline \multirow[t]{3}{*}{ Pengetahuan } & Baik & 23 & 85 & 4 & 15 & 27 & 100 & \\
\hline & Cukup & 12 & 36 & 21 & 64 & 33 & 100 & 0.000 \\
\hline & Total & 35 & 58 & 25 & 42 & 60 & 100 & \\
\hline \multirow[t]{3}{*}{ Sikap } & Baik & 32 & 80 & 8 & 20 & 40 & 100 & \\
\hline & Cukup & 3 & 15 & 17 & 85 & 20 & 100 & 0.000 \\
\hline & Total & 35 & 58 & 25 & 42 & 60 & 100 & \\
\hline
\end{tabular}

Data pada tabel 1 menunjukkan bahwa Berdasarkan observasi yang dilakukan pada responden, tentang studi korelasional antara citra tubuh dengan aktivitas fisik ditemukan distribusi pada kategori puas yaitu $92 \%$ atau 35 responden sedangkan distribusi responden dikataegori tidak puas yaitu $8 \%$ atau 4 responden. Analisis hubungan dalam penelitian ini menggunakan uji chi square, dikatakan berhubungan jika nilai $p$ value $<0.05$. Berdasarkan hasil analisis pada penelitian ini ditemukan $p$-value sebesar 0,000 hal ini berarti ada korelasi antara citra tubuh dengan aktivitas fisik.

Penelitian yang dilakukan oleh Ritan et al (2018) pada mahasiswa keperawatan strata 1 program A STIKES RS Baptis didapatkan bahwa sebagian besar responden dengan citra tubuh sedang yaitu sebanyak 63 responden $(88,7 \%)$, sedangkan body iamge 
baik sebanyak 4 responden $(5,6 \%)$ dari jumlah total 71 responden $(100 \%)$. Setelah dilakukan uji statistik dengan menggunakan uji Spearmen Rho didapatkan nilai $\mathrm{p}=0,034$ yaitu Ho ditolak dan Ha diterima, sehingga dapat disimpulkan ada hubungan gangguan citra tubuh dengan aktivitas fisik olahraga pada mahasiswa obesitas prodi keperawatan strata 1 porgram A STIKES RS Baptis Kediri. Berdasarkan hasil penelitian, dapat diketahui adanya hubungan gangguan citra tubuh dengan aktivitas fisik olahraga pada mahasiswa responden perempuan lebih beresiko mengalami gangguan citra tubuh. Hal ini bisa terjadi karena wanita cenderung memiliki perhatian yang lebih besar terhadap penampilan tubuh dibandingkan dengan laki-laki.

Penelitian dari Putra (2017) menyatakan bahwa citra tubuh digambarkan sebagai persepsi seseorang terhadap bentuk tubuhnya. Citra tubuh digunakan oleh individu untuk menilai dirinya sendiri. Citra tubuh yang negatif cenderung lebih banyak terjadi pada perempuan. Hal ini berdampak terhadap perbedaan motivasi perempuan dalam melakukan aktivitas berolahrag. Citra tubuh yang negatif membatasi pilihan seseorang terhadap tempat melakukan aktivitas fisik, serta berhubungan dengan perbedaan pola makan atlet. Aktivitas fisik berdampak positif terhadap penurunan citra tubuh yang negatif, dan lebih efektif apabila dikombinasikan dengan pandangan perfeksionisme positif, dengan jenis aktivitas olahraga yang dipilih berupa jenis resistance sessions.

Berdasarkan distribusi responden tentang korelasi antara pengetahuan dan aktivitas fisik, ditemukan paling banyak mahasiswa yang memiliki tingkat pengetahuan baik dengan aktivitas fisik cukup sebanyak 23 responden atau 85\%. Paling sedikit mahasiswa yang memiliki tingkat pengetahuan baik dengan akivitas fisik kurang sebanyak 4 responden atau 15\%. Dari hasil uji Chi square, dikatakan berhubungan jika nilai $p$-value $<0.05$. Dengan melihat hasil analisis pada penelitian ini ditemukan nilai $p$ value sebesar 0.000 dengan begitu menegaskan bahwa ada korelasi antara pengetahuan dengan akivitas fisik.

Penelitian yang dilakukan oleh Widiyoga (2020), ditemukan adanya hubngan antara tingkat pengetahuan dengan aktivitas fisik pada 34 responden, yakni 23 responden perempuan dan 11 responden laki-laki, di analisis menggunakan Kendal-tau B. Hasil penelitian ini terdapat hubungan tingkat pengetahuan dengan pengaturan aktivitas fisik $(\mathrm{p}=0,006<\alpha=0,01)$. Menurut Noviyanti (2017), pengetahuan mengenai kebugaran erat hubungan dengan frekuensi aktivitas fisik, dimana semakin tinggi pengetahuan maka semakin tinggi pula frekuensi aktivitas fisiknya dalam rangka meningkatkan kebugaran jasmani. Seseorang yang memiliki pengetahuan baik mengenai aktivitas fisik tanpa disadari dapat meningkatkan kepercayaan dirinya untuk lebih giat melakukan aktivitas fisik guna menunjang kebugaran fisik.

Berdasarkan distribusi responden tentang korelasi antara sikap dengan aktivitas fisik ditemukan paling banyak mahasiswa yang memiliki tingkat sikap baik dengan aktivitas fisik cukup yaitu sebanyak 32 responden atau $80 \%$. Paling sedikit mahasiswa yang memiliki tingkat sikap cukup dengan akivitas fisik cukup sebanyak 3 responden atau 20\%. Dari hasil uji Chi square, dikatakan berhubungan jika nilai $p$-value $<0.05$. Dengan melihat hasil analisis pada penelitian ini ditemukan nilai p sebesar 0.000 dengan begitu, sikap berhubungan secara signifikan dengan akivitas fisik

Penelitian dari Waluya (2019) melakukan penelitian terhadap responden dengan jumlah sampel sebanyak 61 orang yang terbagi menjadi dua kelompok yaitu intervensi (30 orang) dan kelompok kontrol (31 orang). Hasil analisis menunjukan terdapat pengaruh signifikan Suppotive Educative Nursing Intervention (SENI) terhadap 
pengetahuan $(p$-value $=0,000)$ dan sikap $(p$-value $=0,000)$ penyintas kanker payudara tentang aktivitas fisik. Tidak ada pengaruh signifikan SENI dalam meningkatkan intensitas aktivitas fisik penyintas kanker payudara ( $p$-value $=0,413)$. SENI memberikan pengaruh signifikan terhadap pengetahuan dan sikap penyintas kanker payudara tentang aktivitas fisik.

Penelitian dari Verdiana (2019) Hasil penelitian menunjukkan bahwa aktivitas fisik merupakan faktor risiko dominan terhadap kejadian DM di Indonesia. Masyarakat yang memiliki sikap kebiasaan hanya melakukan aktifitas ringan mempunyai peluang untuk terkena DM 2,9 kali dibandingkan dengan masyarakat yang memiliki sikap kebiasaan melakukan aktifitas berat, sedangkan masyarakat yang memiliki sikap kebiasaan melakukan aktivitas sedang mempunyai peluang lebih rendah terkena DM yaitu 1,8 kali dibandingkan dengan aktivitas berat. Semakin berat aktivitas fisik yang dilakukan maka semakin sedikit kemungkinan terkena DM. Ditemukan adanya hubungan sikap kebiasan melakukan aktivitas fisik untuk mencegah DM.

Penelitian yang dilakukan oleh Farradika (2019) dengan respoden sejumlah 846 mahasiswa Fikes Uhamka berpartisipasi dalam penelitian ini. Analisis data menggunakan uji Chi square untuk mengetahui hubungan antara sikap dengan aktifitas fisik dengan determinannya sikap aktivitas fisik. Penelitian ini memberikan hasil bahwa rata-rata skor Metabolic Equivalent (MET) adalah 1420,33 $\pm 2384,297$. Responden yang memiliki aktivitas fisik yang rendah sebesar 47,8\%, aktivitas fisik sedang sebesar 39,6\% dan aktivitas fisik tinggi hanya $12,6 \%$ responden. Ada hubungan yang bermakna sikap positif terhadap aktivitas fisik, dan persepsi terhadap aktivitas fisik. Penelitian dari Cendra (2017) melakukan penelitian pada 193 responden mahasiswa mengenai hubungan sikap dengan aktivitas fisik dengan korelasi rank spearman sebesar 0,966, artinya terdapat hubungan antara sikap dngan aktivitas fisik

\section{PENUTUP}

Kesimpulan dari penelitian ini yaitu terdapat hubungan antara citra tubuh, pengetahuan, sikap dengan tingkat aktivitas fisik pada mahasiswa FKM UNSRAT selama pandemi Covid-19. Oleh karena itu, perlu merancang program perkuliahan untuk meminimalisir kejenuhan mahasiswa saat proses belajar-mengajar.

\section{REFERENSI}

Ammar A, Brach M, Trabelsi K, Chtourou H, Boukhris O, Masmoudi L, et al. (2020). Effects of COVID-19 home confinement on eating behaviour and physical activity: Results of the ECLBCOVID19 international online survey. Nutrients. 12(6): 1583

Apriana, W. 2015. Hubungan Aktivitas Fisik dengan Kualitas Tidur Remaja di Yogyakarta. Universitas Gadjah Mada. Tesis. Yogyakarta.

Cendra, R., \& Gazali, N. (2019). Intensitas Olahraga Terhadap Perilaku Sosial. Media Ilmu Keolahragaan Indonesia, 9(1), 13-17.

Farradika, Y., Umniyatun, Y., Nurmansyah, M. I., \& Jannah, M. (2019). Perilaku Aktivitas Fisik dan Determinannya pada Mahasiswa Fakultas Ilmu-Ilmu Kesehatan Universitas Muhammadiyah Prof. Dr. Hamka. ARKESMAS (Arsip Kesehatan Masyarakat), 4(1), 134-142.). Jakarta.

Noviyanti, R. D., \& Marfuah, D. (2017). Hubungan pengetahuan Gizi, Aktivitas fisik, dan pola makan terhadap status gizi remaja di kelurahan purwosari Laweyan Surakarta. URECOL, 421-426. 
Nurhadi, J. (2020). Pengaruh Pandemi Covid-19 terhadap Tingkat Aktivitas Fisik pada Masyarakat Komplek Pratama, Kelurahan Medan Tembung. Jurnal Health Sains, 1(5), 294-298.

Riskawati, Y.K., Prabowo, E.D., dan Rasyid, H.A. (2018). Tingkat aktivitas fisik mahasiswa program studi pendidikan: Jurnal Health Sains, 3(1), 1-8.

Riyanto, P., \& Mudian, D. (2019). Pengaruh aktivitas fisik terhadap peningkatan kecerdasan emosi siswa. Journal Sport Area, 4(2), 339-347.

Ritan, A. F. G., Murdhiono, W. R., \& Syafitri, E. N. (2018). Hubungan body image dengan pola makan dan aktivitas fisik pada mahasiswa obesitas di Fakultas Ilmu Kesehatan Universitas Respati Yogyakarta. Ilmu Gizi Indonesia, 2(1), 25-32.

Putra, A. (2017). Body Image dan Hubungannya dengan Aktivitas Berolahraga. Jurnal Penjakora. Journal Sport Area, 2(2), 88-97.

Tripathi, R., Makeen, H. A., Albarraq, A. A., Meraya, A. M., Tripathi, P., Faroug, H., \& Ibrahim, S. (2019). Knowledge, attitude and practice about osteoporosis in southwestern Saudi Arabia: a cross-sectional survey. International Journal of Health Promotion and Education, 57(1), 13-22.

Veridiana, N. N., \& Nurjana, M. A. (2019). Hubungan Perilaku Konsumsi dan Aktivitas Fisik dengan Diabetes Mellitus di Indonesia.Buletin Penelitian Kesehatan, 47(2), 97-106.

Waluya, J. G. (2019). Pengaruh Supportive Educative Nursing Intervention (SENI) Terhadap Pengetahuan, Sikap Dan Intensitas Aktivitas Fisik Penyintas Kanker Payudara. Doctoral dissertation. Universitas Padjajaran. Bandung

Welong, S. S., Manampiring, A. E., \& Posangi, J. (2020). Hubungan antara kelelahan, motivasi belajar, dan aktivitas fisik terhadap tingkat prestasi akademik. JURNAL BIOMEDIK: JBM, 12(2), 125-131.

Widiyoga, R. C., Saichudin, S., \& Andiana, O. (2020). Hubungan Tingkat Pengetahuan tentang Penyakit Diabetes Melitus pada Penderita terhadap Pengaturan Pola Makan dan Aktivitas Fisik. Sport Science and Health, 2(2), 152-161.

World Health Organization (2018). ACTIVE-A technical package for increasing physical activity (online) diakses dari http://apps.who.int/iris/bitstrem/handle/10665/275415/9789241514804eng.pdf?ua=1 pada 14 Mei 2021 